\title{
РОБОЧІ ЯКОСТІ ТА ПОКАЗНИКИ НЕРВОВОЇ ДІЯЛЬНОСТІ СОБАК ПОРОДИ СЕРЕДНЬОАЗІАТСЬКА ВІВЧАРКА
}

Була Людмила Валер'янівна

кандидат сільськогосподарських наук Сумський національний аграрний університет ORCID: https://orcid.org/0000-0002-4698-9307

E-mail: bula.snau@gmail.com

Павленко Юлія Миколаївна кандидат сільськогосподарських наук, доцент Сумський національний аграрний університет ORCID: https://orcid.org/0000-0002-4128-122X E-mail: jasjulia@ukr.net

Свисенко Софія Валеріївна Аспірант спеціальності 204-ТВППТ Сумський національний аграрний університет ORCID: https://orcid.org/0000-0001-8761-7676

E-mail: ursula1708@ukr.net

Малікова Альона Іванівна Аспірант спеціальності 204-ТВППТ Сумський національний аграрний університет ORCID: https://orcid.org/0000-0002-4277-0172

E-mail: lelikunique2@gmail.com

При проведенні досліджень вивчались матеріали первинного зоотехнічного обліку Сумського обласного центру собаківництва КСУ. Робочі якості службових собак вивчалися за допомогою звітів про іспити та змагання собак породи середньоазіатська вівчарка з ЗКД (Загальний курс дресирування), КС (Караульна служба), результатів тестування сили нервової системи службових собак на племінних оглядах і виводках. Дослідженнями встановлено, що оцінка робочих якостей та показників нервової діяльності поголів'я собак породи середньоазіатська вівчарка Сумської області відповідає вимогам до робочих якостей службових собак. Щодо оцінки спадковості передачі службових якостей було визначено, що

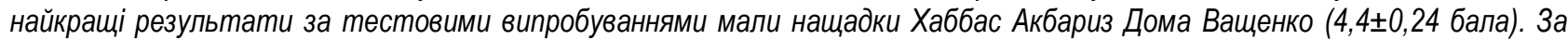

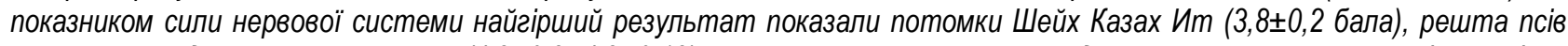
мали майже однаковий результат $(4,2 \pm 0,2,4,2 \pm 0,12)$. Що стосується соиіальної адаптації і караульної служби, найбіль-

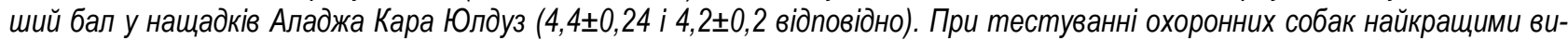
явилися потомки Юкон-Джоні Палій. Найбільший позитивний кореляційний взаємозв'язок між показниками робочих якостей батьків та нащадків собак туркменського типу спостерігається за оцінкою караульної служби $(0,46 \pm 0,18)$ при ступені вірогідності $P \geq 0,99$. Також статистично вірогідний значний позитивний зв'язок $(0,41 \pm 0,19, P \geq 0,95)$ був за оцінкою сили нервової системи тварин, що вказує на ефективний добір племінних тварин у даній популяції. Найбільший коефічієнт успадковування (31,9\%) спостерігається за оцінкою караульних якостей середньоазіатських вівчарок, які є характерною ознакою породної поведінки.

Ключові слова: середньоазіатська вівчарка, робочі якості, нервова діяльність, спадковість.

DOI: https://doi.org/10.32845/bsnau.Ivst.2019.4.13

Кінологічна служба - це елітний підрозділ фахівців, готових виконувати оперативно-бойові завдання з високою ефективністю. Їх найголовніша зброя - це не тільки навички володіння вогнепальною зброєю або навички рукопашного бою, а й добре злагоджена бойова пара, що складається 3 кінолога і службового собаки [14].

Домашній собака (Canislupusacquisis) $€$ універсальним службовим ресурсом для людини через низку фізичних і поведінкових характеристик. Через гостроту свого нюху собак використовують для виявлення заборонених речовин та предметів, таких як: наркотичні, психотропні речовини та їхні прекурсори, вибухівку, зброю і боєприпаси до неї. Крім того, у правоохоронних органах собак використовують для пошуку злочинця, речових доказів, для патрульнорозшукової, конвойної та вартової служб $[12,18]$.
Саме тому кількісна оцінка і опис індивідуальних особливостей у поведінці робочих собак на даний час $€$ об'єктом багатьох досліджень вітчизняних та закордонних науковців-кінологів. Менш вивченим $€$ прогнозуючий зв'язок між поведінковими особливостями конкретної собаки і результатами роботи на службі людині $[4,9,15,16]$. Спеціалістам, які використовують робочих собак в оперативному плані, потрібні методи для раннього виявлення напряму розвитку чи формування поведінкових особливостей, які потенційно можуть бути проблематичними або корисними на майбутній службі людині. Ці методи повинні бути придатними для використання на ранніх етапах процесу відбору, щоб уникнути значних інвестицій у собак, які не зможуть ефективно працювати у майбутньому [17].

Визначальне значення робочих якостей собак служ-

Вісник Сумського національного аграрного університету 
бових порід підтверджується вітчизняними фахівцямикінологами. У визначенні - «собаки службових порід» закладено призначення тварин: виконувати певну службу (роботу) - захисно-вартову, розшукову, вартову, пошуковорятувальну та інші. Та найдосконаліший за екстер'єром собака, який не здатний успішно піддаватися дресируванню і нести службу, не має цінності для службового собаківництва. I навпаки, утримання та розведення працездатних особин, навіть за наявності у них недоліків у екстер'єрі, цілком виправдано [5,7].

Службові (робочі) якості - це здатність собак до дресирування, вироблення навичок загального курсу дресирування (ЗКД) і спеціального курсу (СКД) - захисної служби $(3 \mathrm{C})$, караульної служби (КС), розшукової служби (РС) і інших спеціальних служб.

Аналізуючи роботи дослідників, що спеціалізуються на службовому собаківництві було виявлено, що універсальної породи для використання немає. І хоча всі звикли до німецької вівчарки, впродовж багатьох десятків років конкуруючою породою є східноєвропейські вівчарки. Деякі вважають, що останні мають більш врівноважений рухливий тип темпераменту, ніж «німці», а також стверджують, що собаки даної породи відрізняються спокоєм та витримкою $[6,8,13]$. Проте, в якості вартових,німецькі вівчарки поступаються середньоазіатським та кавказьким вівчаркам. Як зазначає Висоцький В.Б. у своїх працях, саме «азіати» мають вроджену недовірливість до сторонніх, дуже розвинений охоронний реслекс та високий інтелектуальний рівень, у комплексі з інстинктивним прагненням атакувати в найбільш вразливе місце противника $[1,2,3]$.

Враховуючи актуальність питання вибору породи собак для службового використання об'єктом наших досліджень стали середньоазіатські вівчарки.

Матеріали та методи досліджень. При проведенні досліджень вивчались матеріали первинного зоотехнічного обліку Сумського обласного центру собаківництва КСУ. Робочі якості службових собак вивчалися за допомогою звітів про іспити та змагання собак з ЗКД (Загальний курс дресирування), КС (Караульна служба), результатів тестування сили нервової системи службових собак на племінних оглядах і виводках.

Тестування нервової системи проводили в два етапи. На першому етапі визначається сила нервової системи за реакцією тварини на сильний звуковий подразник, а саме, звук пострілу із стартового пістолета на відстані 15 м від неї. Другий етап включає в себе перевірку захисних якостей за допомогою «умовного зловмисника» - фігуранта з захисним рукавом. Для більшої зручності обробки інформації була застосована оцінка сили нервової системи в цифровому виразі за п'ятибальною шкалою. В залежності від вираженості реакції на постріл тварини одержували таку оцінку:

5 - у собаки відсутня реакція на постріл;

4 - в момент пострілу собака повертає голову в бік стріляючого, або несильно сіпається;

3 - відбувається зміна положення тіла собаки після пострілу, або проявлення агресії в бік стріляючого;

2 - собака боїться пострілу, але після команди господаря заспокоюється і продовжує виконувати навички;

1 - панічний страх пострілу, собака не чує команд господаря і намагається втекти з майданчика.

Для перевірки соціальної адаптації тварин використовували методику, яка прийнята для оцінки даного показника на племінних оглядах. Оцінка досліджуваної поведінки проводилась в умовних одиницях за п'ятибальною шкалою, a саме:

5 - доброзичливе, спокійне відношення до помічників; й агресії;

4 - орієнтовна реакція, сторожкість без ознак страху помічників;

3 - орієнтовна реакція, собака проявляє агресію в бік

2 - невпевнена поведінка, пасивно-оборонна реакція в бік помічників;

1 - собака боїться помічників, намагається уникнути близького контакту з ними.

Таблиця мінімальних балів оцінки роботи собаки на випробуваннях з караульної служби

\begin{tabular}{|c|c|c|c|c|c|}
\hline \multirow[b]{2}{*}{ № 3/П } & \multirow[b]{2}{*}{ Найменування навичок } & \multirow[b]{2}{*}{$\begin{array}{c}\text { Вища оцінка } \\
100 \text { балів }\end{array}$} & \multicolumn{3}{|c|}{ Оцінка роботи собаки } \\
\hline & & & $\begin{array}{c}\text { Диплом І ст. } \\
90 \text { балів }\end{array}$ & $\begin{array}{c}\text { Диплом II ст. } \\
80 \text { балів }\end{array}$ & $\begin{array}{c}\text { Диплом III ст. } \\
60 \text { балів }\end{array}$ \\
\hline & Поведінка собаки на посту & 20 & 18 & 16 & 12 \\
\hline & Дальність обгавкування, захист поста & 20 & 18 & 16 & 12 \\
\hline & Активність обгавкування & 20 & 18 & 16 & 12 \\
\hline & Відношення до ласощів & 20 & 18 & 16 & 12 \\
\hline & Відношення до пострілу & 20 & 18 & 16 & 12 \\
\hline
\end{tabular}

Біометрична обробка одержаних даних проводилась за методом варіаційної статистики за формулами, наведеними Є.К. Меркур'євою [9].

Успадковуваність показників робочих якостей у собак породи середньоазіатська вівчарка визначалася через подвоєний коефіцієнт кореляції $(r)$ між спорідненими групами тварин та коефіцієнт успадковуваності $\left(h^{2}\right)$, розрахований за допомогою однофакторного дисперсійного аналізу.

Величина критерію вірогідності встановлювалася при рівнях: $P \geq 0,95$ - 95,0\%, $P \geq 0,99$ - 99,0\%, $P \geq 0,999$ - 99,9\% за допомогою критеріїв Стьюдента і Фішера.

Математична обробка статистичного матеріалу проводилась за допомогою ЕОМ з використанням програмного забезпечення фірми "Microsoft"(операційна система "Windows-10", електронні таблиці “Excel”).

Результати досліджень. Середньоазіатська вівчарка $є$ однією з найвідоміших службових порід собак, висока популярність якої тримається протягом усієї ії столітньої історії. На території Сумської області ця порода є дуже популярною і входить у трійку найпоширеніших порід.

На даний час середньоазіатську вівчарку не можна назвати однорідною породою. Багато спеціалістів виділяють в породі чотири типи: туркменський, таджицький, узбецький та казахський. Вважається, що найкращі представники породи, які зберегли типові ознаки аборигенної вівчарки, зосереджені у Туркменії. Їх ще називають алабаями, азиатами та 
туркменськими вовкодавами. Найбільш поширеним в породі на даний час залишається саме туркменський тип. В Сумський області також зустрічаються собаки казахського типу. Падіння чисельності типу казахських собак пояснюється тим, що поступово старе поголів'я собак замінюється на більш «модний» туркменський тип.

Середньоазіатська вівчарка за функціональним призначенням відноситься до службових порід собак. Службові (робочі) якості собаки - це здатність його до дресирування, вироблення навичок слухняності і спеціального курсу. До складу поняття «службові якості» входить також рівень дресирування собак (тобто чіткість і безвідмовність виконання ними вироблених навичок), пристосованість тварин до життя і роботи в різних умовах зовнішнього середовища. За даними таблиці 2 встановлено, що 82,5\% всіх досліджуваних собак пройшли тестові випробування; $62,5 \%$ курс караульної служби; 52,5\% - тестування охоронних собак. I лише 5\% - ЗКД (загальний курс дресирування).

Таблиця 2

Аналіз робочих якостей собак породи середньоазіатська вівчарка

\begin{tabular}{|c|c|c|c|c|c|c|c|}
\hline \multirow{4}{*}{ № } & \multirow{4}{*}{ Курс дресирування } & \multicolumn{4}{|c|}{ Тип } & \multirow{2}{*}{\multicolumn{2}{|c|}{ Всього }} \\
\hline & & \multicolumn{2}{|c|}{ Туркменський } & \multicolumn{2}{|c|}{ Казахський } & & \\
\hline & & $\mathrm{n}$ & $\%$ & $\mathrm{n}$ & $\%$ & $\mathrm{n}$ & $\%$ \\
\hline & & 36 & $\%$ & 4 & $\%$ & 40 & $\%$ \\
\hline 1 & Тестові випробування & 29 & 80,6 & 4 & 100 & 33 & 82,5 \\
\hline 2 & ЗКД & 2 & 5,6 & - & - & 2 & 5,0 \\
\hline 3 & Караульна служба & 22 & 61,1 & 3 & 75 & 25 & 62,5 \\
\hline 4 & Соціальна адаптація & 30 & 83,3 & 2 & 50 & 32 & 80,0 \\
\hline 5 & $\begin{array}{l}\text { Тестування } \\
\text { охоронних собак }\end{array}$ & 18 & 50,0 & 3 & 75 & 21 & 52,5 \\
\hline
\end{tabular}

При проведенні аналізу даних таблиці 3 чітко видно, що за оцінкою тесту караульна служба (4,67 $\pm 0,33$ бали) собаки казахського типу значно перевершують туркменський $(4,29 \pm 0,29$ бала).

Результати тестування охоронних собак свідчать, що найкращі показники $(4,33 \pm 0,33$ бала) у казахського типу, і трохи відстають туркмени (4,2 $\pm 0,37$ бала), що свідчить про гарні типово етологічні властивості середньоазіатської вівчарки.

За результатами перевірки сили нервової системи за допомогою звукового подразника встановлено, що собаки туркменського типу $(4,1 \pm 0,23$ бала) перевищують казахський (4,0 \pm 0,58 бала). Тому для покращення нервової сис- теми нащадків при формуванні батьківських пар доцільно використовувати плідників туркменського типу.

За оцінкою тесту, який визначав соціальну адаптацію собак туркмени (4,27 $\pm 0,3$ бала) перевершили казахський тип (4,0 $\pm 1,0$ бала) на 0,27 балів.

Вищенаведені результати досліджень дають змогу зробити висновок, що в цілому поголів'я собак породи середньоазіатська вівчарка Сумської області відповідає вимогам до робочих якостей службових собак. Собаки казахського типу перевершують туркменський за основними показниками робочого використання. Тому їх необхідно активно використовувати у племінному розведенні для покращення робочих якостей середньоазіатської вівчарки в регіоні.

Таблиця 3

Оцінка показників сили нервової системи та робочих якостей собак, бал

\begin{tabular}{|c|c|c|c|c|c|c|c|}
\hline \multirow[b]{2}{*}{ № } & \multirow{2}{*}{\multicolumn{2}{|c|}{$\begin{array}{l}\text { Внутрішньо } \\
\text { породний тип }\end{array}$}} & \multicolumn{5}{|c|}{ Показники робочих якостей } \\
\hline & & & $\begin{array}{c}\text { Сила нервової } \\
\text { системи }\end{array}$ & $\begin{array}{l}\text { Соціальна } \\
\text { адаптація }\end{array}$ & $\begin{array}{l}\text { Караульна } \\
\text { служба }\end{array}$ & $\begin{array}{c}\text { Тестування } \\
\text { охоронних собак }\end{array}$ & Захисні якості \\
\hline \multirow{3}{*}{1} & \multicolumn{2}{|c|}{$n$} & 32 & 27 & 24 & 15 & 23 \\
\hline & \multirow{2}{*}{ Туркменський } & $\mathrm{M} \pm \mathrm{m}$ & $4,1 \pm 0,23$ & $4,27 \pm 0,3$ & $4,29 \pm 0,29$ & $4,2 \pm 0,37$ & $3,0 \pm 0,58$ \\
\hline & & $\mathrm{Cv}, \%$ & 24,9 & 23,6 & 17,6 & 19,9 & 25 \\
\hline \multirow{3}{*}{2} & \multicolumn{2}{|l|}{$\mathrm{n}$} & 3 & 2 & 3 & 3 & 3 \\
\hline & \multirow{2}{*}{ Казахський } & $\mathrm{M} \pm \mathrm{m}$ & $4,0 \pm 0,58$ & $4,0 \pm 1,0$ & $4,67 \pm 0,33$ & $4,33 \pm 0,33$ & $3,33 \pm 0,67$ \\
\hline & & $\mathrm{Cv}, \%$ & 25 & 35,4 & 12,4 & 13,3 & 26,6 \\
\hline
\end{tabular}

3 метою з'ясування наявності спадковості передачі службових якостей нами було проведено дослідження показників вищої нервової діяльності та робочих якостей 5 плідників і 25 їхніх нащадків породи середньоазіатська вівчарка у Сумській області. Результати дослідження представлені у таблиці 4.

Було встановлено, що найкращі результати за тестовими випробуваннями мали нащадки Хаббас Акбариз

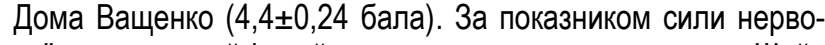
вої системи найгірший результат показали потомки Шейх Казах Ит (3,8 0,2 бала), решта псів мали майже однаковий результат $(4,2 \pm 0,2,4,2 \pm 0,12)$. Що стосується оцінки соціальної адаптації і караульної служби, найбільший бал у нащад-

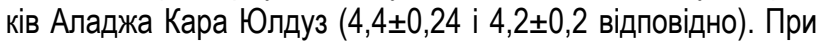
тестуванні охоронних собак найкращими виявилися потомки Юкон-Джоні Палій. 
Аналіз оцінки робочих якостей нащадків племінних псів, бал

\begin{tabular}{|c|c|c|c|c|c|c|c|}
\hline \multirow{2}{*}{ № $\Pi /$ п } & \multirow{2}{*}{\multicolumn{2}{|c|}{ Показники }} & \multicolumn{5}{|c|}{ Плідники } \\
\hline & & & \multirow{2}{*}{$\begin{array}{c}\text { Карім } \\
5 \\
\end{array}$} & \multirow{2}{*}{$\begin{array}{l}\begin{array}{c}\text { Хаббас Акбариз } \\
\text { Дома Ващенко }\end{array} \\
5\end{array}$} & \multirow{2}{*}{$\begin{array}{c}\text { Шейх Казах Ит } \\
5 \\
\end{array}$} & \multirow{3}{*}{$\begin{array}{c}\begin{array}{c}\text { Аладжа Кара } \\
\text { Юлдуз }\end{array} \\
5 \\
42+02\end{array}$} & \multirow{2}{*}{$\begin{array}{c}\begin{array}{c}\text { ЮКОН - Джон } \\
\text { Палій }\end{array} \\
5 \\
\end{array}$} \\
\hline 1 & Кількість нащағ & & & & & & \\
\hline \multirow{2}{*}{2} & \multirow{2}{*}{ Сила нервової системи } & $\mathrm{M} \pm \mathrm{m}$ & $4,2 \pm 0,2$ & $4,4 \pm 0,24$ & $3,8 \pm 0,2$ & & $4,2 \pm 0,2$ \\
\hline & & $\mathrm{Cv}, \%$ & 9,52 & 11,13 & 10,53 & 9,52 & 9,52 \\
\hline \multirow{2}{*}{3} & \multirow{2}{*}{ Соціальна адаптація } & $\mathrm{M} \pm \mathrm{m}$ & $3,8 \pm 0,2$ & $4,2 \pm 0,2$ & $4,2 \pm 0,12$ & $4,2 \pm 0,2$ & $4,2 \pm 0,2$ \\
\hline & & $\mathrm{Cv}, \%$ & 10,53 & 9,52 & 9,52 & 9,52 & 9,52 \\
\hline \multirow{2}{*}{4} & \multirow{2}{*}{ Караульна служба } & $\mathrm{M} \pm \mathrm{m}$ & $4,2 \pm 0,32$ & $4,0 \pm 0,32$ & $4,0 \pm 0,32$ & $4,4 \pm 0,24$ & $4,2 \pm 0,2$ \\
\hline & & Cv, \% & 15,81 & 15,81 & 15,81 & 11,13 & 9,52 \\
\hline \multirow{2}{*}{5} & \multirow{2}{*}{$\begin{array}{c}\text { Тестування охоронних } \\
\text { собак } \\
\end{array}$} & $\mathrm{M} \pm \mathrm{m}$ & $4,0 \pm 0,2$ & $4,0 \pm 0,32$ & $3,8 \pm 0,2$ & $4,2 \pm 0,2$ & 4,0 \\
\hline & & $\mathrm{Cv}, \%$ & 9,52 & 15,81 & 10,53 & 9,52 & 0,0 \\
\hline \multirow{2}{*}{6} & \multirow{2}{*}{ Захисні якості } & $\mathrm{M} \pm \mathrm{m}$ & 3,0 & $3,2 \pm 0,2$ & $2,8 \pm 0,42$ & $3,0 \pm 0,32$ & $3,2 \pm 0,2$ \\
\hline & & $\mathrm{Cv}, \%$ & 0,0 & 9,52 & 15,81 & 15,81 & 9,52 \\
\hline
\end{tabular}

Як відомо, ступінь фенотипової різноманітності нащадків відповідає певною мірою генотиповій різноманітності батьків, що й визначає більшу або меншу ефективність добору. У наших дослідженнях ознаки поведінки тварин, які ми вивчали, можна спостерігати як у жіночих, так і у чолові- чих особинах. Зважаючи на те, що дані показники вищої нервової діяльності можна визначити в обох батьків, коефіцієнт успадковуваності ми виражали через подвоєний коефріцієнт кореляції між фенотиповим рівнем ознаки батьків та потомків (рис.1).

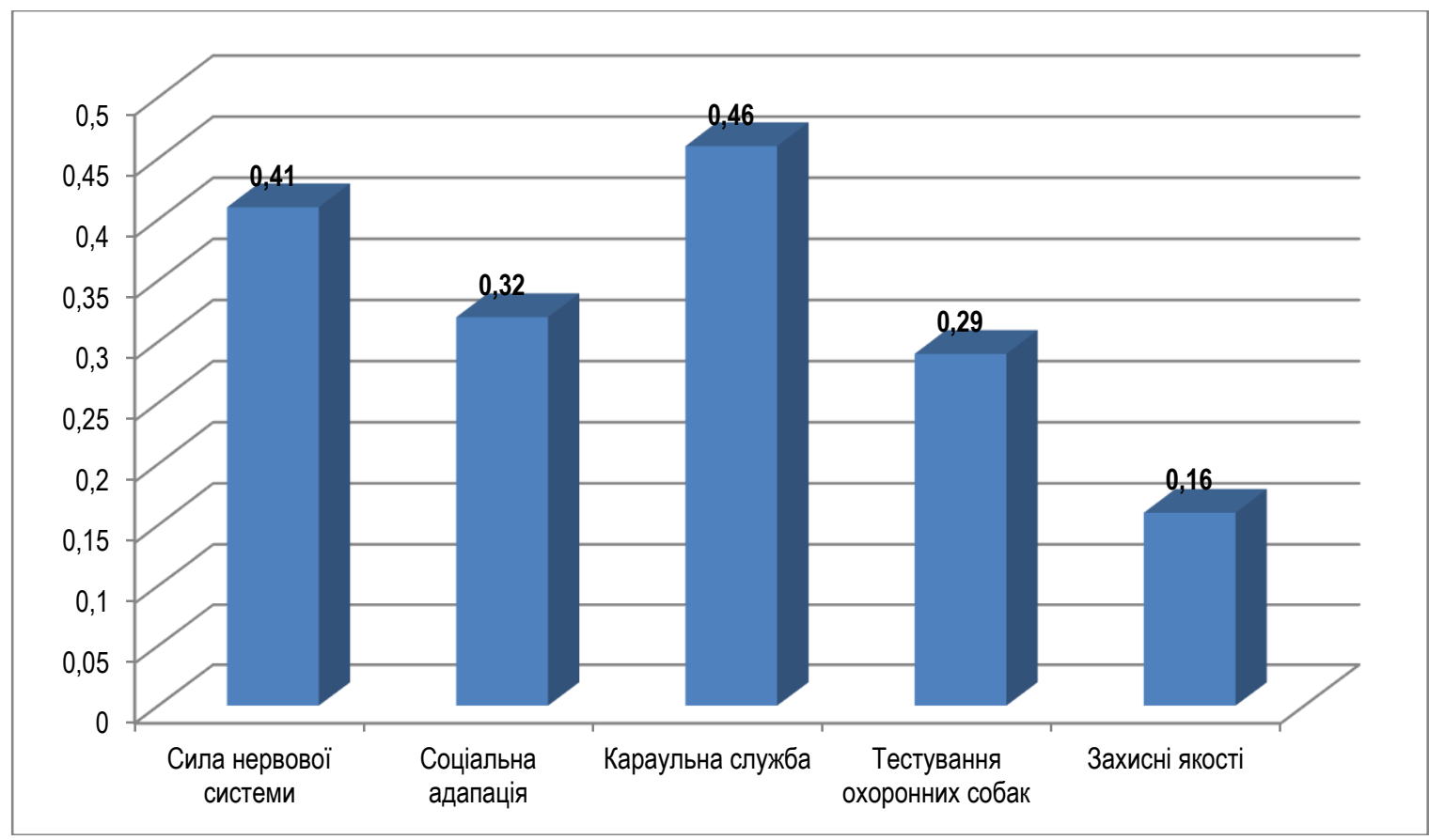

Рис. 1. Успадковуваність показників робочих якостей собак туркменського типу, вирахувана через подвоєний коефіцієнт кореляції бутьки-потомки, $h^{2}$

3 вище наведеного графіку спостерігаємо, що найвищим коефіцієнтом успадковуваності характеризується оцінка роботи собак з караульної служби $(0,46 \pm 0,18)$ при достатньому ступені достовірності $\mathrm{P} \geq 0,99$. Також значний та статистично вірогідний коефіцієнт успадковуваності отримано за оцінкою сили нервової системи тварин $(0,41 \pm 0,19$; $\mathrm{P} \geq 0,95)$, що вказує на можливість ефективного добору племінних тварин у даній популяції для подальшого удоскона- лення цих поведінкових ознак. За іншими показниками робочих якостей успадковуваність була статистично невірогідною ( $\mathrm{P}>0,95)$.

Для більш об'єктивного вивчення впливу умовного генотипу батьків на робочі якості їхніх нащадків ми розрахували коефіцієнт успадковуваності за показниками робочих якостей за допомогою однофакторного дисперсійного аналізу (рис.2). 


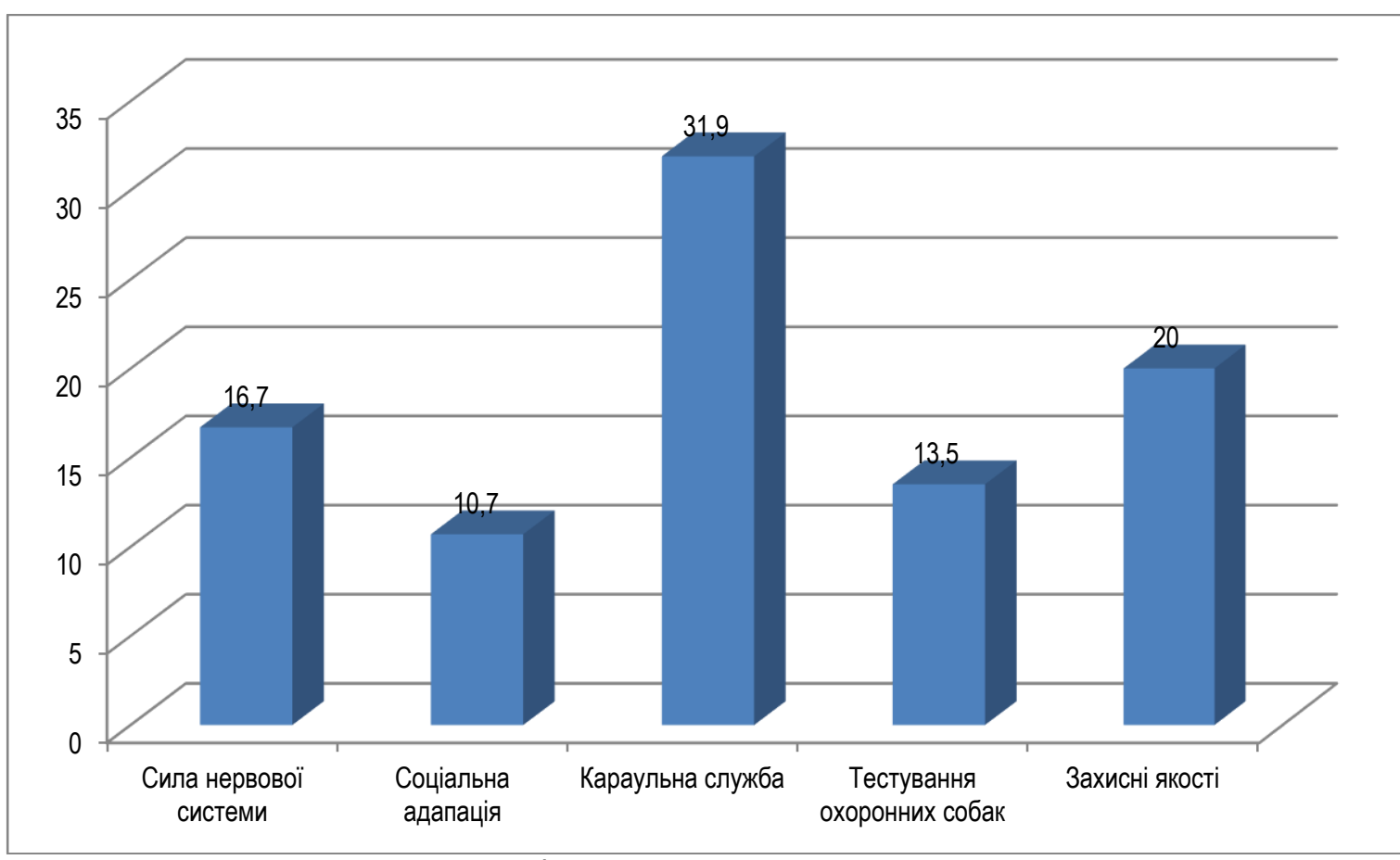

Рис.2. Успадковуваність показників робочих якостей середньоазіатських вівчарок туркменського типу, вирахувана методом однофакторного дисперсійного аналізу, $h^{2}$

Отримані показники успадковуваності, що наведені на рисунку 2, вирахувані методом однофакторного дисперсійного аналізу, підтверджують попередні дані, вирахувані методом подвоєного коефіцієнта кореляції бутьки-потомки (див. рис. 1), що найбільший коефіцієнт успадковуваності $(31,9 \%)$ спостерігається також за оцінкою караульних якостей середньоазіатських вівчарок, які $є$ характерною особливістю породної поведінки. На жаль, за рештою показників коефіцієнт успадковуваності був статистично невірогідним $(\mathrm{P}>0,95)$.

Висновки. Дослідженнями встановлено, що оцінка робочих якостей та показників нервової діяльності поголів'я собак породи середньоазіатська вівчарка Сумської області відповідає вимогам до робочих якостей службових собак. Щодо оцінки спадковості передачі службових якостей було визначено, що найкращі результати за тестовими випробуваннями мали нащадки Хаббас Акбариз Дома Ващенко. За показником сили нервової системи найгірший результат показали потомки Шейх Казах Ит. Що стосується соціальної адаптації і караульної служби, найбільший бал у нащадків Аладжа Кара Юлдуз. При тестуванні охоронних собак найкращими виявилися потомки Юкон-Джоні Палій.

Найвищі коефріцієнти успадковуваності робочих якостей собак туркменського типу, вирахувані через подвоєний коефріцієнт кореляції бутьки-потомки, отримано за оцінкою караульної служби $\left(h^{2}=0,46\right)$ та сили нервової системи $\left(h^{2}=0,41\right)$ тварин. Отримані рівні коефріцієнтів успадковуваності засвідчують про високі можливості селекції собак туркменського типу за цими ознаками.

Про ефективний добір середньоазіатських вівчарок за оцінкою ознаки караульних якостей, підтверджує отриманий достовірний рівень коефріцієнта успадковуваності $\left(h^{2}=0,319\right)$, вирахуваний методом дисперсійного аналізу.

\section{Список використаної літератури:}

1. Высоцкий В.Б. Дрессировка отечественных волкодавов. М.: Аквариум-Принт, 2004. 36с.

2. Высоцкий В.Б. Охранные модели поведения служебных собак или модель охранного поведения хороших собак. Твоё собачье дело. 2001. №1. URL: http://www.pets.kiev.ua/sd/sd1-01/ohranmodeli.html (дата звернення 27.01.2019).

3. Высоцкий В.Б. Собака сопровождения. Донецк: Сталкер, 2001. URL: https://www.litmir.me/br/?b=30262\&p=1 (дата звернення 31.01.2019).

4. Гриценко В.В. Формы научения и способы дрессировки собак для поиска взрывчатых веществ, взрывных устройств, оружия и боеприпасов. М: ЮНИТИ: Закон и право, 2012. 172 с.

5. Кичигин И.С. Служебные качества немецких овчарок. Студенческий научный форум: Материалы XII Международной студенческой научной конференции. URL: https://scienceforum.ru/2019/article/2018014673 (дата звернення 19.01.2019).

6. Копылова С.В., Токарев И.Н. Влияние породных особенностей на работоспособность собак. Материалы Х Международной студенческой научной конференции «Студенческий научный форум». URL: http://scienceforum.ru/2018/article/2018006604 (дата звернення 19.01.2019).

7. Мазовер, А.П. Племенное дело в служебном собаководстве. М.: Наука, 2003. 186с.

8. Маслов К. Н. Пограничная кинология России: 110 лет на службе по охране государственной границы. М: Граница. 2005. $444 \mathrm{c}$.

9. Меркурьева Е.К., Шангин-Березовский Г.Н. Генетика с основами биометрии. М.: Колос, 1983. 400с. 
10. Муллагалямова 3.Х., Гиниятуллин М. Г. Рабочие качества служебных собак в зависимости от их возраста. Материалы IX Международной студенческой научной конференции «Студенческий научный форум» URL: http://scienceforum.ru/2017/article/2017040854 (дата звернення 19.01.2019).

11. Мусин И.Ф., Исламова С.Г. Служебные качества собак породы немецкая овчарка в зависимости от типа высшей нервной деятельности. Материалы IX Международной студенческой научной конференции «Студенческий научный форум». URL: http://scienceforum.ru/2017/article/2017038726 (дата звернення 19.01.2019).

12. Наказ Міністерства внутрішніх справ України від 01.11.2016 №1145 «Про затвердження Інструкції з організації діяльності кінологічних підрозділів Національної поліції України». База даних «Законодавство України». URL: https://zakon.rada.gov.ua/laws/show/z1544-16 (дата звернення 15.01.2019).

13. Сахаров Н.А. Техника дрессировки служебных собак. М.: МиР, 2003. 250 с.

14. Целоусов В.А., Токарев И.Н. Определение рабочих качеств служебных собак в Уфсин ФКУ ИК-13 г. Уфы. Материалы IX Международной студенческой научной конференции «Студенческий научный фрорум». URL: http://scienceforum.ru/2017/article/2017037814 (дата звернення 19.01.2019).

15. Шарипов А.А., Токарев И.Н. Рабочие качества собак породы немецкая овчарка в отделе МВД по Туймазинскому району Республики Башкортостан. Материалы VII Международной студенческой научной конференции «Студенческий научный форум». URL: https://scienceforum.ru/2015/article/2015015986 (дата звернення19.01.2019).

16. David L.Sinn, Samuel D.Gosling, Stewart Hilliard Personality and performance in military working dogs: Reliability and predictive validity of behavioral tests. URL: https://doi.org/10.1016/j.applanim.2010.08.007 (дата звернення 21.01.2019).

17. Karen Bradya, Nina Cracknellb, Helen Zulcha, Daniel S. Millsa. Factors associated with long-term success in working police dogs. URL: https://doi.org/10.1016/j.applanim.2018.07.003 (accessed: 21.01.2019).

18. La ToyaJ.Jamieson, Greg S.Baxter, Peter J.Murray Identifying suitable detection dogs. URL: https://doi.org/10.1016/j.applanim.2017.06.010 (accessed: 21.01.2019).

\section{References:}

1. Vysockij, V.B., 2004. Dressirovka otechestvennyh volkodavov [Training of domestic wolfhounds]. M.: Akvarium-Print, 36.

2. Vysockij, V.B., 2001. Ohrannye modeli povedeniya sluzhebnyh sobakili model ohrannogo povedeniya horoshih sobak [Guard models of behavior of service dogs or a model of guard behavior of good dogs]. Tvoyo sobache delo. no.1. Available at: <http://www.pets.kiev.ua/sd/sd1-01/ohranmodeli.html> [Aaccessed 27 January 2019].

3. Vysockij, V.B., 2001. Sobaka soprovozhdeniya [Escort dog]. Donezk: «Stalker». Available at:< https://www.litmir.me/br/?b=30262\&p=1> [Aaccessed 31 January 2019].

4. Gricenko, V.V., 2012. Formy naucheniya i sposoby dressirovki sobak dlya poiska vzryvchatyh veshestv, vzryvnyh ustrojstv, oruzhiya i boepripasov [Forms of training and methods of dog training for the search for explosives, explosive devices, weapons and ammunition]. M: YuNITI : Zakon i parvo, 172.

5. Kichigin, I.S. Sluzhebnye kachestva nemeckih ovcharok [Service qualities of German shepherds]. Studencheskij nauchnyj forum. Proceedings of the 10rd International Student Scientific Conference. Available at: <https://scienceforum.ru/2019/article/2018014673> [Aaccessed 19 January 2019].

6. Kopylova, S.V., Tokarev, I.N. Vliyanie porodnyh osobennostej na rabotosposobnost sobak [The influence of breed characteristics on the performance of dogs]. Studencheskij nauchnyj forum. Proceedings of the 12rd International Student Scientific Conference. Available at: <http://scienceforum.ru/2018/article/2018006604> [Aaccessed 19 January 2019]. Nauka, 186

7. Mazover, A.P., 2003. Plemennoe delo v sluzhebnom sobakovodstve [Breeding business in service dog breeding]. M.:

8. Maslov, K.N., 2005. Pogranichnaya kinologiya Rossii: 110 let na sluzhbe po ohrane gosudarstvennoj granicy [Russian border cynology: 110 years in the service of protecting the state border]. M: Granica. 444.

9. Merkureva, G.N., Shangin-Berezovskij, E.K., 1983. Genetika s osnovami biometrii [Genetics with the basics of biometrics]. M.: Kolos, 400 .

10. Mullagalyamova, Z.H., Giniyatullin, M.G. Rabochie kachestva sluzhebnyh sobak v zavisimosti ot ih vozrasta [Working qualities of service dogs depending on their age] Studencheskij nauchnyj forum. Proceedings of the 9rd International Student Scientific Conference. Available at: <http://scienceforum.ru/2017/article/2017040854> [Aaccessed 19 January 2019].

11. Musin, I.F., Islamova, S.G. Sluzhebnye kachestva sobak porody nemeckaya ovcharka v zavisimosti ot tipa vysshej nervnoj deyatelnosti [Service qualities of German Shepherd dogs depending on the type of higher nervous activity]. Studencheskij nauchnyj forum. Proceedings of the 9rd International Student Scientific Conference. Available at: <http://scienceforum.ru/2017/article/2017040854> [Aaccessed 19 January 2019].

12. The order of the Ministry of Internal Affairs of Ukraine 2016 no.1145. Pro zatverdzhennya Instrukciyi z organizaciy i diyalnosti kinologichnih pidrozdiliv Nacionalnoyipoliciyi Ukrayini. Zakonodavstvo Ukrayini. Available at: <https://zakon.rada.gov.ua/laws/show/z1544-16> [Aaccessed 15 January 2019].

13. Saharov, N.A., 2003. Tehnika dressirovki sluzhebnyh sobak [Dog Training Technique]. M.: MiR, 250

14. Celousov, V.A., Tokarev, I.N. Opredelenie rabochih kachestv sluzhebnyh sobak v Ufsin FKU IK-13 g. Ufy [Determination of working qualities of service dogs in Ufsin FKU IK-13 of Ufa]. Studencheskij nauchnyj forum. Proceedings of the 9rd International Student Scientific Conference. Available at: < http://scienceforum.ru/2017/article/2017037814> [Aaccessed 19 January 2019

15. Sharipov, A.A. ,Tokarev, I.N. Rabochie kachestva sobak porody nemeckaya ovcharka v otdele MVD po Tujmazinskomu rajonu Respubliki Bashkortostan [The working qualities of dogs of the German Shepherd breed in the department of the Ministry of Internal Affairs in the Tuymazinsky district of the Republic of Bashkortostan]. Studencheskij nauchnyj forum. Proceedings of the 7rd 
International Student Scientific Conference. Available at: <https://scienceforum.ru/2015/article/2015015986> [Aaccessed 19 January 2019].

16. David L.Sinn, Samuel D.Gosling, Stewart Hilliard. Personality and performance in military working dogs: Reliability and predictive validity of behavioral tests. Available at: <https://doi.org/10.1016/j.applanim.2010.08.007> [Aaccessed 21 January 2019].

17. Karen Bradya, Nina Cracknellb, Helen Zulch, Daniel S. Millsa. Factors associated with long-term success in working police dogs. Available at: <https://doi.org/10.1016/j.applanim.2018.07.003> [Aaccessed 21 January 2019].

18. La Toya J.Jamieson, Greg S.Baxter, Peter J.Murray. Identifying suitable detection dogs. Available at: <https://doi.org/10.1016/j.applanim.2017.06.010> [Aaccessed 21 January 2019].

Pavlenko Yu.M.,

Bula L.V.,

Svysenko S.V.,

Malykova A.I.

Working qualities and indicators of nervous activity of breed dogs Central Asia

During the research, the materials of primary accounting of the Sumy Regional Center of Dog Breeding of KSU were studied. The working qualities of service dogs were studied with the help of exam reports and competitions of dogs of the breed Central Asian Shepherd Dog with OKD (General Training Course), COP (Guard Service), the results of testing the strength of the nervous system of service dogs on breeding examinations and broods. Studies have shown that the assessment of working qualities and indicators of nervous activity of the livestock of breed dogs of the Central Asian Shepherd of Sumy region meets the requirements for the working qualities of service dogs. Concerning the assessment of the inheritance of the transfer of official qualities, it was determined that the best results of the test tests were descendants of the Habbas Akbariz House of Vaschenko (4.4 \pm 0.24 points). In terms of nervous system strength, Sheikh Kazakh It's progeny showed the worst result (3.8 \pm 0.2 points), while the rest of the dogs had almost the same result $(4.2 \pm 0.2,4.2 \pm 0.12)$. In terms of social adaptation and guard duty, the highest score among Aladz's descendants is Kara Yulduz (4.4 \pm 0.24 and $4.2 \pm 0.2$, respectively). When testing guard dogs, the best were the descendants of Yukon-Johnny Pali. The highest positive correlation between the performance indicators of parents and offspring of Turkmen-type dogs is observed by the sentencing service $(0.46 \pm 0.18)$ at a probability of $P \geq 0.99$. A statistically significant significant positive relationship $(0.41 \pm$ $0.19, P \geq 0.95)$ was also statistically significant, indicating the strength of the nervous system of animals, indicating the efficient selection of breeding animals in this population. The highest inheritance coefficient (31.9\%) is observed in the assessment of the guarding qualities of Central Asian shepherds, which is a characteristic feature of breed behavior.

Key words: Central Asian shepherd, working qualities, nervous activity, heredity.

Дата надходження до редакції: 19.10.2019 р. 